\title{
PENGARUH FISIOTERAPI DADA TERHADAP KUANTITAS TIDUR PASIEN PENYAKIT PARU OBSTRUKSI KRONIK
}

\author{
Orlando Riki Akbar, Hermansyah, Martha Heryati
}

\author{
Poltekkes Kemenkes Bengkulu, Jurusan Keperawatan Jl. Indragiri No. 03 \\ Email : riki.orlando@yahoo.com
}

\begin{abstract}
Individuals with Chronic Obstructive Pulmonary Disease ( COPD ) often experience a disruption in the fulfillment of the need for rest and sleep. The results of the survey conducted in inpatient RSUD Dr. M. Yunus Bengkulu earned 5 COPD patients experience sleep disturbances and did not know act chest physiotherapy and omissions chest physiotherapy to increase the quantity of sleep of patients with COPD . This type of research is Pre Experiment with using design one group pre and post test . Population in this research is that COPD patients are running the entire hospitalization in Melati, Kenanga, dan Teratai RSUD Dr. M. Yunus Bengkulu . Samples taken by accidental sampling of 30 samples. Data analysis of the 30 respondents were Univariate and Bivariate by paired $t$ - test test at $\alpha 5 \%$. The results showed that there was an increase in the average COPD patient sleep after nursing actions chest physiotherapy $(p=0.000)$. Hospital room nurse suggested to perform nursing interventions to improve sleep in COPD patients with chest physiotherapy.
\end{abstract}

Keywords : Sleep Frequency, Fisisoterapi chest

\begin{abstract}
Abstrak : Individu dengan Penyakit Paru Obstruksi Kronik (PPOK) sering mengalami gangguan dalam pemenuhan akan kebutuhan istirahat dan tidurnya. Hasil survey yang dilakukan di instalasi rawat inap RSUD M. Yunus Bengkulu didapatkan 5 orang pasien PPOK mengalami gangguan tidur dan tidak tahu tindakan fisioterapi dada dan tidak dilakukannya tindakan fisioterapi dada untuk meningkatkan kuantitas tidur pasien PPOK. Jenis penelitian yang digunakan adalah Pre Experiment dengan menggunakan desain one group pre and post test. Populasi dalam penelitin ini adalah seluruh pasien PPOK yang menjalankan rawat inap di ruangan Melati, Kenanga, dan Teratai RSUD Dr. M. Yunus Bengkulu. Sampel diambil secara accidental sampling sebanyak 30 sampel. Analisis data terhadap 30 responden dilakukan secara Univariat dan Bivariat dengan uji paired t-tes pada $\alpha 5 \%$. Hasil penelitian menunjukkan bahwa ada peningkatan rata-rata tidur pasien PPOK setelah dilakukan tindakan keperawatan fisioterapi dada $(\mathrm{p}=0,000)$. Suggested to the nurse in the inpatient unit to perform nursing interventions to improve sleep in COPD patients with chest physiotherapy.
\end{abstract}

Kata kunci : Frekuensi Tidur, Fisisoterapi dada

PPOK merupakan kondisi irreversible yang berkaitan dengan dispnea saat aktivitas dan penurunan aliran masuk dan keluar udara paru-paru. Obstruksi parsial/hampir total jalan nafas seperti pada Penyakit Paru Obstruktif Kronik (PPOK) yang menyebabkan reduksi aliran udara beragam tergantung pada tingkat keparahan penyakitnya (Perhimpunan Dokter Spesialis Penyakit Dalam Indonesia, 2003).

WHO menunjukkan bahwa pada tahun 2010 PPOK menempati urutan ke-4 sebagai penyebab utama kematian di dunia (WHO, 2010). Di Amerika Serikat dibutuhkan dana sekitar 32 juta US\$ dalam setahun untuk menanggulangi penyakit ini, dengan jumlah pasien sebanyak 16 juta orang dan lebih dari 100 ribu orang meninggal. Hasil survei penyakit tidak menular oleh Direktorat Jenderal PPM \& PL di 5 rumah sakit propinsi di Indonesia (Jawa Barat, Jawa Tengah, Jawa Timur, Lampung, dan Sumatera Selatan) pada tahun 2004, menunjukkan PPOK menempati urutan pertama penyumbang angka kesakitan (35\%), diikuti asma bronkial bronkial (33\%), kanker paru $(30 \%)$ dan lainnya (2\%) (Depkes RI, 2004, dalam Syaputra, 2005). Pada Survai Kesehatan Rumah Tangga (SKRT) bronkitis kronik dan emfisema menduduki peringkat ke - 6 dari 10 penyebab tersering kematian di Indonesia (SKRT, 2004). 
Penyakit Paru Obstruksi Kronik (PPOK) mempunyai tanda dan gejala yakni Batuk (mungkin produktif atau non produktif), dan perasaan dada seperti terikat, Mengi saat inspirasi maupun ekspirasi yang dapat terdengar tanpa alat bantu, Pernafasan cuping hidung, Ketakutan dan diaforesis, batuk produktif dengan sputum berwarna putih keabu-abuan, yang biasanya terjadi pada pagi hari, Inspirasi ronkhi kasar dan whezzing, Sesak nafas (JaapCATrappenburg, 2004, dalam Syaputra, 2005).

Salah satu akibat yang timbul dari penyakit paru obstruksi kronik (PPOK) adalah menurunnya fungsi tidur penderitanya. Salah satu kebutuhan yang terpenting bagi manusia adalah tidur. Seseorang yang dalam keadaan sehat memerlukan tidur sekitar 6-8 jam setiap malam, hal tersebut merupakan kebutuhan tidur yang normal (Kozier dan Oliveri, 2002). Pola tidur seseorang akan berbeda tergantung pada pekerjaan atau kebiasaan seseorang dan keadaan sakit. Sementara itu dalam keadaan yang tidak baik atau sakit, maka Frekuensi dan kuantitas tidur seseorang akan terganggu. Frekuensi tidur adalah ritme biologis yang paling kompleks. Sehingga bila irama fisik \& psikologis meningkat atau mengalami trauma atau infeksi sistem pernafasan, maka seseorang akan mudah terbangun dan bilamana rendah orang akan tertidur (Kozier. dan Oliveri, 2002).

Gangguan kuantitas tidur secara umum merupakan suatu keadaan dimana individu mengalami atau mempunyai risiko perubahan dalam jumlah dan kenyamanan tidur (Uliyah, 2004). Apabila seseorang sudah mengalami perubahan dalam jumlah dan kuantitas tidurnya maka dapat dilakukan tindakan fisioterapi dada. Fisioterapi adalah suatu cara atau bentuk pengobatan untuk mengembalikan fungsi suatu organ tubuh dengan memakai tenaga alam. Dalam fisioterapi tenaga alam yang dipakai antara lain listrik, sinar, air, panas, dingin, massage dan latihan yang mana penggunaannya disesuaikan dengan batas toleransi penderita sehingga didapatkan efek pengobatan (Luchinur, 2003, dalam Padli, 2004).

Fisioterapi dada merupakan salah satu dari pada fisioterapi yang sangat berguna bagi penderita penyakit respirasi baik yang bersifat akut maupun kronis. Fisioterapi dada ini walaupun caranya kelihatan tidak istimewa tetapi ini sangat efektif dalam upaya mengeluarkan sekret dan memperbaiki ventilasi pada pasien dengan fungsi paru yang terganggu (Potter, 2005).

Hasil penelitian yang dilakukan oleh Syaputra (2005) di Rumah Sakit Baturahma Padang, menggambarkan bahwa sebagian besar responden menyatakan kualitas maupun kuantitas tidur pasien membaik setelah dilakukan fisioterapi dada sebesar $78,4 \%$ dan tindakan fisioterapi dada memiliki pengaruh yang signifikan terhadap frekuensi tidur pasien. $(\mathrm{p}=0,000)$.

Berdasarkan data yang diperoleh di sub bagian medik RSUD. M. Yunus Bengkulu jumlah pasien paru yang berobat ke RSUD. M. Yunus Bengkulu pada tahun 2011 berjumlah 890 orang, dan yang menderita PPOK sebanyak 165 orang. Data awal yang dilakukan oleh peneliti di RSUD Dr. M. Yunus Bengkulu tahun 2012, dari 6 orang pasien yang mengalami penyakit paru obstruksi kronik (PPOK) semuanya mengalami gangguan tidur dikarenkan batuk dan produksi sekret yang berlebih. Berdasarkan data tersebut, penelitian ini penting untuk mengetahui sejauh mana tindakan fisioterapi dada berpengaruh terhadap frekuensi pasien PPOK.

\section{BAHAN DAN CARA KERJA}

Jenis penelitian yang digunakan adalah Pre Experiment dengan rancangan one group pre and post test dimana rencana ini tidak menggunakan kelompok pembanding tetapi sudah dilakukan observasi pertama yang memungkinkan menguji perubahanperubahan yang terjadi setelah adanya eksperiment (Notoatmodjo, 2010). Populasi dalam penelitian ini adalah seluruh 
pasien paru yang dirawat diruangan rawat inap RSUD M. Yunus Bengkulu tahun 2013, dengan perkiraan jumlah berdasarkan jumlah pasien tahun yaitu sebesar 890 orang. Sampel dalam penelitian ini adalah Tehnik pengambilan sampel adalah pasien paru yang dirawat diruangan rawat inap RSUD M. Yunus Bengkulu tahun 2013. Pengambilan sampel dengan teknik Accidental Sampling dengan besar sampel menurut Gay dan Diehl (1992 dalam Kasjono, 2009) bahwa sampel minimal pada penelitian pre experiment sebasar 30 orang.

\section{HASIL}

\section{Analisis Univariat}

Analisis univariat pada penelitian ini untuk melihat nilai mean median, nilai minimal-maksimal, standar deviasi, dan 95\% confidience interval (CI) dari mean sebelum dan sesudah dilakukan terapi aktivitas kelompok sosialisasi

Tabel 1. Distribusi Rata - Rata Kuantitas Tidur Pasien PPOK Sebelum Dan Sesudah Dilakukan Fisioterapi Dada Di Ruang Rawat Inap RSUD M. Yunus Bengkulu

\begin{tabular}{lccccc}
\hline $\begin{array}{l}\text { Kuantitas } \\
\text { Tidur }\end{array}$ & N & $\begin{array}{c}\text { Mean } \\
\text { median }\end{array}$ & SD & $\begin{array}{c}\text { Min- } \\
\text { Mak }\end{array}$ & $\begin{array}{c}\mathbf{9 5 \%} \\
\text { CI of } \\
\text { mean }\end{array}$ \\
\hline Sebelum & 30 & 5,33 & 0,959 & $4-7$ & $4,98-$ \\
Intervensi & & 5,00 & & & 5,69 \\
Sesudah & 30 & 6,73 & 0,785 & $5-8$ & $6,44-$ \\
Intervensi & & 7,00 & & & 7,03 \\
\hline
\end{tabular}

Hasil analisis menunjukan rata-rata kuantitas tidur pasien PPOK sebelum dilakukan fisioterapi dada adalah 5,33 jam dengan standar deviasi 0,959 jam . Dari hasil estimasi interval dapat disimpulkan bahwa $95 \%$ diyakini rata-rata kuantitas tidur pasien PPOK sebelum dilakukan fisioterapi dada adalah diantara 4,98 jam sampai dengan 5,69 jam. Didapatkan rata rata kuantitas tidur pasien PPOK sesudah dilakukan tindakan fisioterapi dada adalah 6,73 jam dengan standar defisiasi 0,785 jam. Hasil estimasi interval dapat disimpulkan bahwa 95\% diyakini rata - rata kuantitas tidur pasien PPOK setelah dilakukan fisioterapi dada adalah diantara 6,44 jam sampai dengan 7,03 jam.

\section{Analisis Bivariat}

Analisa bivariat dilakukan untuk mengetahui adanya peningkatan kuantitas tidur sebelum dan sesudah dilakukan intervensi (fisioterapi dada), yakni dengan menguji paired t-test pada $\alpha 5 \%$ one tail (satu sisi).

Tabel 2. Distribusi perbedaan rata - rata tingkat kuantitas tidur responden sebelum dan sesudah dilakukan tindakan fisioterapi dada diruang rawat inap RSUD M. Yunus Bengkulu (n : 30)

\begin{tabular}{lccccc}
\hline $\begin{array}{l}\text { Kuantitas } \\
\text { Tidur }\end{array}$ & Mean & SD & SE & $\begin{array}{c}\text { T } \\
\text { (df) }\end{array}$ & $\begin{array}{c}\text { P } \\
\text { value }\end{array}$ \\
\hline $\begin{array}{l}\text { Sebelum } \\
\text { intervensi }\end{array}$ & 5,33 & 0,959 & 0,143 & 8,573 & 0,000 \\
$\begin{array}{l}\text { Sesudah } \\
\text { intervensi }\end{array}$ & 6,73 & 0,785 & 0,175 & & \\
\hline
\end{tabular}

Hasil uji statistik menunjukan bahwa nilai $\mathrm{P}=0,000<\alpha 5 \%$ (one tail) artinya ada peningkatan rata-rata kuantitas tidur pasien PPOK sesudah tindakan fisioterapi dada lebih tinggi dibandingkan rata-rata kuantitas tidur pasien PPOK sebelum dilakukan tindakan fisioterapi dada. Dapat disimpulkan ada pengaruh tindakan keperawatan fisioterapi dada terhadap peningkatan tidur pasien PPOK.

\section{PEMBAHASAN}

Gambaran Kuantitas Tidur Pasien PPOK Sebelum dan Sesudah Dilakukan Tindakan Fisioterapi Dada

Sebelum pelaksanaan perlakuan (intervensi) dengan tindakan fisioterapi dada untuk melihat pengaruhnya terhadap kuantitas tidur pasien PPOK, dilakukan pengukuran pertama kuantitas tidur terhadap seluruh responden dengan menggunakan " lembar observasi kuantitas tidur pasien PPOK".

Hasil penelitian didapatkan rata-rata kuantitas tidur pasien PPOK sebelum di- 
lakukan tindakan fisioterapi dada 5,33 jam (95\% CI: 4,98-5,69). Sedangkan hasil hasil uji statistik menunjukan bahwa nilai $\mathrm{P}=0,000 \propto 5 \%$ (one tail) artinya ada peningkatan rata-rata kuantitas tidur pasien PPOK sesudah tindakan fisioterapi dada lebih tinggi dibandingkan rata-rata kuantitas tidur pasien PPOK sebelum dilakukan tindakan fisioterapi dada. Dapat disimpulkan ada pengaruh tindakan keperawatan fisioterapi dada terhadap peningkatan tidur pasien PPOK. analisis didapatkan rata-rata kuantitas tidur pasien PPOK sesudah dilakukan tindakan fisioterapi dada adalah 6.73 jam (95\% CI: 6,44 - 7,03).

Hal ini menunjukan bahwa setiap pasien PPOK mengalami gangguan kuantitas tidur, keadaan ini sesuai dengan penelitian yang dilakukan oleh Syaputra (2005) tentang frekuensi tidur pasien PPOK bahwa dari 16 responden dalam tingkat frekuensi tidur sedang sebanyak 1 orang $(6,25 \%), 15(93,75 \%)$ orang yang memiliki tingkat frekuensi tidur baik setelah dilakukan tindakan fisioterapi dada. Hal ini sesuai dengan tujuan dilakukannya fisioterapi dada yang dikatakan oleh Brunner dan Suddarth (2001), yaitu tujuan fisioterapi dada adalah untuk membuang sekresi Bronchial memperbaiki ventilasi dan meningkatkan efisiensi otot-otot pernafasan.

Tindakan fisioterapi dada yang dilakukan terhadap pasien PPOK ini dapat mengurangi penumpukan sekret di saluran nafas dan akan memudahkan pasien untuk tidur tanpa adanya gangguan pada jalan nafas. Dengan tindakan fisioterapi dada ini, diharapkan jalan nafas dapat bersih sehingga responden dapat tidur dengan nyenyak. Tidur dikatakan nyenyak bila seluruh organ tubuh dalam keadaan relaksasi tanpa disertai adanya stressor secara emosional maupun fisik (Maslow dalam Syaputra, 2005). Lebih lanjut Guyton and Hall (2005), menyatakan bahwa bahwa selama tidur seluruh aktivitas organ tubuh akan berkurang dan aktivitas sel akan meningkat dengan peningkatan sel-sel baru. Sehingga bila sirkulasi darah dalam tubuh lancar maka akan meningkatkan kesegaran saat responden bangun pada pagi harinya

\section{Perbedaan Rata - Rata Kuantitas Tidur Pasien PPOK Sebelum dan Sesudah Dilakukan Tindakan Fisioterapi Dada}

Hasil penelitian menunjukan rata rata perbedaan kuantitas tidur pasien PPOK sebelum dan sesudah tindakan fisioterapi dada adalah 1,4 jam. Hasil penelitian juga menunjukan ada kenaikan rata - rata kuantitas tidur pasien PPOK sesudah dibandingkan dengan sebelum tindakan fisioterapi dada ( $\mathrm{p}=0,000)$.

Keadaan ini menunjukan semua responden mengalami kenaikan kuantitas tidurnya setelah dilakukan tindakan fisioterapi dada. Hal ini di perkuat oleh pendapat Winariani (2002, dalam Syaputra, 2005) sebagai penatalaksanaan pasien paru, fisioterapi dada memberi omset yang lebih cepat dibandingkan obat - obat oral maupun intravena.

Hasil obsevasi selama penelitian responden yang mengalami kekurangan kuantitas tidur ditandai dengan beberapa hal, diantaranya menjadi lemas, tidak bersemangat pada siang hari, terdapat kantung pada kelopak mata bawah, dan terdapat mata panda di sekitar mata. Lama tidur normal untuk orang dewasa antara 6 - 8 jam sehari (Pusdiknakes, 1989, dalam Padli, 2004) sehingga dengan tindakan fisioterapi dada dapat meningkatkan kenyamanan responden dalam aktifitas tidur, dengan demikian bila tidak ada gangguan yang dapat mengurangi kenyamanan tidur responden, maka responden akan mudah untuk tidur kembali.

\section{KESIMPULAN}

Berdasarkan hasil penelitian dan pembahasan pengaruh tindakan fisioterapi dada terhadap kuantitas tidur pasien PPOK, maka dapat dibuat kesimpulan sebagai berikut: hasil analisis didapatkan rata-rata kuantitas tidur pasien PPOK sebelum 
dilakukan tindakan fisioterapi dada adalah dibawah frekuensi tidur orang dewasa normal (6-8 jam) sedangkan rata-rata kuantitas tidur pasien sesudah dilakukan tindakan fisioterapi dada adalah dalam rentang frekuensi tidur orang dewasa normal (6-8 jam), dengan kenaikan 1,4 jam. Ada pengaruh tindakan fisioterapi dada terhadap peningkatan rata-rata kuantitas tidur pasien PPOK.

Berdasarkan hasil penelitian disarankan bagi RSUD Dr. M Yunus Bengkulu agar perawat di ruang rawat inap dapat meningkatkan kemampuan dan keterampilannya dalam pelaksanaan tindakan fisioterapi dada pada pasien dengan gang-

\section{DAFTAR RUJUKAN}

American Toraciety Society 2005. Engsiklopedia Kedokteran. http.www.Google.com

Brunner dan Suddarth. 2001. Keperawatan Medikal Bedah. Jakarta : EGC.

Brooker, Chris. 2009. Ensiklopedia Keperawatan. Jakarta: EGC

Eggram, B. 2006, Ilmu Penyakit Paru, Jakarta

Fitri, luchi nur. 2009. http://luchinurfitri.blog.friendster.com/2009/0 l/fisioterapi-dadal .diakses pada 20/10/12

FKUI. 2004. Penyakit Paru Obstruktif Menahun. EGC. Jakarta.

Guyton \& Hall. 2007. Fisiologi Kedokteran. Jakarta : EGC.

Kasjono, H.S., dan Yasril. 2009. Teknik Sampling untuk Penelitian Kesehatan. Jakarta : Graha Ilmu.

Kozier, Oliveri, R 20052. Fundamentals of Nursing : Concepts, Process and Practice $\left(5^{\text {th }}\right.$ ed). California : Addison-Wesley Publishing Co.

Notoatmodjo. 2010. Metodelogi Penelitian Kesehatan. Jakarta :PT Rheneka Cipta

Padli. 2004. Faktor - faktor resiko pasien penyakit obstruksi kronik (PPOK) yang rawat jalan di Rumah Sakit Umum Daerah Abdoel Moeloek Propinsi Lampung. Skripsi. Stikes Tri Madiri Sakti.

Perhimpunan Dokter Spesialis Penyakit Dalam Indonesia. 2003. Buku Ajar Ilmu Penyakit Dalam Jilid II, edisi ketiga, Jakarta: balai Penerbit FKUI guan PPOK, sehingga dapat membantu pasien dalam proses pemulihan. Diharapkan perawat ruangan rawat inap untuk dapat menggunakan tindakan keperawatan fisioterapi dada secara rutin dan optimal sebagai penatalaksanaan kepada pasien PPOK. Bagi penelitian lain diharapkan pada peneliti lain untuk dapat mengkaji fakto lain yang dapat meningkatkan kuantitas tidur pasien PPOK selain denganfisioterapi dada. Penelitiannya dapat dilakukan dengan memperbanyak sampel yang diteliti dan menggunakan kelompok pembanding, dan cara pengambilan sample secara random sehingga didapatkan hasil yang maksimal.

Potter, Patricia A. 2005. Buku Ajar Fundamental Keperawatan. Jakarta: EGC

Price,S.A. dan Wilson, Lorrine M. 2005. Patofisiologi Konsep Klinis Proses-Proses Penyakit. Jakarta : EGC

Potter dan Perry. 2006. Fundamental Keperawatan. Jakarta: EGC

Sander. 2003. Ilmu Penyakit Dalam. Jakarta : Balai Penerbit FKUI.

Survei Kesehatan Rumah Tangga. 2004. dalam http://www.btklsby.go.id/wpcontent/uploads/2010/07/KEPMENKES1022-THN-2008-TTG-PEDOMANPENGENDALIAN-PPOK. Diakses pada hari kamis, 04/10/12.

Syaputra (2005) Perbedaan Pola Tidur Pasien PPOK Setelah Dan Sebelum Dilakukan Tindakan Fisioterapi Dada di Rumah Sakit Baturahma Padang. Skripsi. Tidak Dipublikasikan.

Tawoto dan Wartona. 2006. Kebutuhan Dasar Manusia dan Proses Keperawatan, Jakarta: Salemba Madika.

Uliah. 2004. Kebutuhan Dasar Manusia. Salemba Medika : Jakarta.

WHO. 2010 : diambil dari http://www.who.int/entity/respiratory/ copd/en. Diakses pada hari kamis, 04/10/12

Winariani. 2002. Dalam Keperawatan Medikal Bedah. EGC: Jakarta 